\title{
Productivity Change and Competitiveness as Determinants of National Transformation in Nigeria
}

\author{
Uno Ijim Agbor \\ Department Of Public Administrationuniversity Of Calabar
}

\begin{abstract}
Productivity is a core consideration in the development equation of countries that strive for economic strength, increase in national revenue through foreign exchange earnings and overall improvement in the standard of living of its citizens. It has therefore become a core concept for development planners and institutions. Any country that exhibits a lackluster attitude to productivity is consciously inviting poverty. This paper examines the sanctity of productivity change and competitiveness as a sin qua non to national development and hypothesizes that effective resource diversification to productivity change and competitiveness could reposition Nigeria on the path of national transformation. Basic data for the paper were through literature search. The paper outlines the determinants of productivity change and the place of policy in changing the production direction of Nigeria. It observes that Nigeria productivity is conditioned by a mono resource (Oil). It concludes that a conscious policy direction on resource diversification will place Nigeria in the direction of productivity change. To achieve this, the paper recommends effective collaboration between the state, academia and the industry in the development of knowledge base economy
\end{abstract}

KEYWORDS: Productivity, competitiveness, National transformation, Nigeria

\section{INTRODUCTION}

Productivity is a watchword for many countries of the world including their internal elements such as policy makers, economists, commentators, businesses and employers. Its utility is so diverse that an attempt to ignore it or treat it with levity is a conscious invitation to national decay. It is argued firmly here that a production-less society is a society in utter stagnation, retrogression and atavism. Nigeria's productivity seems to be measured in terms of the quantity of crude oil it produces a day and what sales it makes at the international market. But Conceiving productivity from the rentier perspective as it were in the Nigeria's case is utterly misleading .Nigeria's revenue from oil has dropped drastically from \$140USD per barrel in 2012 to less than \$40USD per barrel in 2016. The unemployment situation is alarming. Banks have began the process of sacking over one thousand staff eventhough the federal government is appealing to them to shelve the mass retrenchment. Nigeria relies much on one major source of revenue (the sale of crude oil). With the reemergence of a new militant group called the Niger Delta Avengers (NDA), and with the recent spate of bombing oil installations in the region, the oil production is likely to drop drastically, further returning Nigeria to the era of president Yar'Adua (2007-2009) where crude oil production a day dropped to all time low of 600 barrels a day. A country with a mono major source of revenue is likely to face economic challenges when that source is no longer viable. The Nigerian economy has been witnessing and is still passing through difficult condition of uncertainty leading to the categorization of the country among the top poorest in the world.

The problem is whether these challenges could be attributed to lack of productivity change. How does competitive productivity accentuate national transformation? Is the Nigerian economy engaged in competitive productivity? The objective of the paper is therefore, to explain the utility of competitive productivity to national transformation in Nigeria. Data for the paper were mostly collected from secondary sources and were qualitatively analyzed.

\section{CONCEPTUALIZING PRODUCTIVITY}

The concept of productivity has attracted diverse explications. From the business/commercial connotation productivity is conceived as the turnover of an organization be it a small company or a big industry when compared to the inputs in terms of materials, labour etc. it employs. This economic view in other words looks at the "rate at which goods and services are produced especially output per unit of labour". Schreyer (2001) aligns with this frequently used definition. For him it is the "ratio of the volume measure of output to a volume measure of input used". It is therefore conceived as the calculated rate of making goods.

Udo-aka (1983) attempts an elaboration of this conception. He argues that productivity connotes the measure of overall efficiency, effectiveness and performance of an organization. This involves quality of output, workmanship, adherence to complaints, customer satisfaction, turnover rate and absence of difficulty in organization. This conception provides a narrow view of productivity as it limits it to just output-input analysis 
and fails to capture the pathway to achieving productivity change. It clearly takes a mechanistic view of productivity.But productivity goes beyond this to capture even structural elements of productivity growth. Samiee (1990) attempted an all-encompassing conception of productivity as any innovation or measure, manipulation, change or adjustment that can improve the performance of organization (e.g. increase output, higher sales level, improved employee morale or reduced operating cost, improved technology) for a given combination of resources. Samiee's view takes into consideration the notion of productivity change which is a vital and unrepudiated element in productivity analysis. This conception expresses a human factor view of productivity.Productivity change refers to the positive result of a combination of changes in technical efficiency, allocative efficiency, and economics of scale (OECD, 2001). It is further decomposed to technological enhancement or change in best practices (technology based productivity) and efficiency change. Technology growth and efficiency are regarded in this case as too biggest factors of productivity. In other words, beyond the factor of input-output analysis, productivity conceptualization must take into consideration the factors that propel its sustainability. It is in this regard that the element of productivity change must be viewed very seriously when discussing productivity in any socio-formation. On this strength, the conception of productivity by the New Zealand productivity Commission makes clearer meaning. For it, "productivity is about how well people combine resources to produce goods and services. For countries, it is about creating more from available resources such as raw materials, labour skills, capital equipment, land, intellectual property, managerial capability and financial capital. With the right choices higher production, higher value and higher incomes can be achieved for every worker". (www.chelsey.co.nz). How do you create more? The necessity and importance of improved technological change becomes obvious.

\section{IMPORTANCE OF ENHANCED PRODUCTIVITY}

Enhanced productivity is very important in the development equation of any society. At the level of a country, if more goods are produced for a given level of input, they are able to consume more, which translates into more resources for the production of other goods. This makes a country better off. It is evident therefore that high productivity will determine the standard of living. High productivity means richness while low productivity tantamount to poverty. A country with high productivity in all fronts attracts the respect of the other countries and this is the source of domination of backward countries by economically and technologically advanced countries of the world. Increased productivity is therefore, a sine-qua-non for a country's transformation. Traded Productivity is likely to improve the standard of living of the citizens because employment opportunities will be created. As the standard of living of a people improves, there is the tendency to be more productive to sustain the standard. More productivity leads to more resources in the hands of the individual and more resources in their hands lead to their ability to purchase goods and services, access better living, better education and contribution to social and environmental programmes as well as acumen to produce more. It is a circle of progress that is relevant in the development percentile of societies. This circle is further presented in the model below.

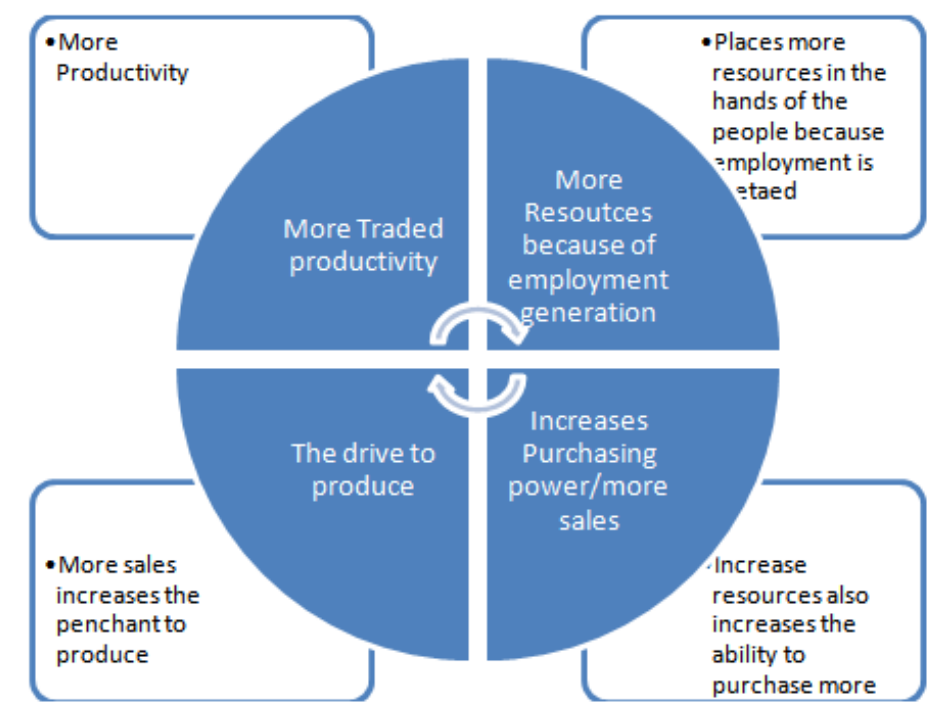

Figure 1: Model of enhanced productivity

Source: Author's configuration 
At the industry level, the necessity of increase productivity has been identified widely. In several forms it can address the following advantages.

\$To the workers it could lead to increase in wages and improvement in the condition of work.

\$ Shareholders can receive enhanced dividend (this is only applicable in a sincere and responsible business environment).

\# Increased productivity can lead to low prices for customers.

\$To the governments, there could be increases in tax payments which can be used to fund social and environmental programmes (again where the society is responsible this can apply).

High productivity can maintain an industry's competiveness or improve their competitiveness in the market place.

\section{DETERMINANTS OF PRODUCTIVITY}

I intend to limit myself to four basic determinants of productivity here. There could be other determinants of productivity depending on the scholarly ingenuity of experts and professionals in the field. I have decided to limit myself to this four because of its all-encompassing character.

One major determining factor of productivity is technological knowhow. It refers to the knowledge and ability to produce goods and services in standard and intelligible ways. In other words, how is the world working in your area of production? The place of technology therefore has become very relevant in stimulating productivity growth in major economies. The place of Information Technology for instance in stimulating productivity has been studied roundly. "Many have hypothesized that IT was behind the resurgence in US aggregate productivity growth in the mid-1990s after twenty years of sluggish performance and that IT has more generally influenced productivity pattern across multiple industries and countries" (Syverson, 2011. www.home.uchicago.edu).Ark, O'mahony and Timmer (2008) blame the European Union sluggish productivity growth within the same period to later emergence and smaller rise of IT investment in European economies. Hubbard (2001) "shows how on-board computers raise average utilization rates of trucks that they are installed in. The computers provide dispatchers real time information on a truck's locations and load status, allowing them to better match the available cartage capacity to innovations in demand" (www.home.uchicago.edu).

It is therefore, clear that where appropriate technology is not robustly applied; productivity could be minimal and will not compete favourably with its counterparts in the developed world.Human capital is another determinant of productivity. We conceptualize human capital here to mean the knowledge and skills workers acquire through education, training and experiments. Let me argue here that machines do not manipulate itself. Even if computer -mediated robots are applied, humans propel them. The human factor in productivity growth is the most important in my view. This is so because the knowledge to produce technology (a necessary component of productivity growth) is brought to bear by humans and the application of such technology is done by man. However, it is not every category of man that is most relevant in productivity enhancement. Well informed humans are necessities in productivity growth. Improving human capacity becomes very imperative and points directly at the nature of the education system. Where the educational calendar is very epileptic owing to frequent strike actions, and where the state of infrastructure is in a deplorable state at all levels of the educational system, one begins to wonder the kind of human capitals such system produces to address productivity needs of the country and face the competition that is necessary to stay in the business. Abowd (2005), Ilmakunnas, Maliranta and Vainiomaki (2004) argued in separate studies that productivity increases with effective worker education. It follows clearly that there must be an intelligent human resources management that necessarily involves training and retraining, effective hiring and placement policies particularly for the entry-level positions that are founded on merit.

Physical capital also determines productivity. It is here conceived "as the stock of equipment and structures that are used to produce goods and services". Material resources at appropriate state are necessary to stimulates productivity growth. This simply defines a good working condition, seen from two perspectives of physical and aesthetic conditions. The physical condition explores the availability of needed infrastructure (power also) and desirable work area. Aesthetics has to do with the attractiveness of offices and work places as well as other measures conducive to the psychological comfort of employees. They have a way of boosting employee morale and leads to improved productivity.Finally, natural resources also play determining role in a people's productivity. This involves inputs into "production that are provided by nature, such as land, rivers, and mineral deposits" (www.web,uvic.ca). Where they are not available in the right quantity for use, productivity could be retarded.The exegesis above suggests that a good infrastructure, adequate machinery, available and adequate materials both human and natural, intelligent use of computer, a good organizational "structure providing for clear lines of communication, authority and accountability, trained and knowledgeable management, and a committed and motivated" staff could enhance productivity (Ubeku, 1983). Personnel motivation is very important in productivity equation. Watson (1963) has been very clear in his submission that no matter how good your people may be, if they do not really feel involved in it, or if they do not really think they are being treated fairly, it is awfully hard to get a business off the ground. 


\section{SECTORAL PRODUCTIVITY: A CROSS COUNTRY ONE FACTOR SURVEY}

I intend here to take a cross country survey of a specific production area that defines the development of countries. The aim is to see Nigeria's rating among the comity of nations

The table below captures electricity production trend and access for selected countries.

TABLE 1: Total Electricity Net Generation (Billion kilowatt hours)

\begin{tabular}{|c|c|c|c|c|c|c|c|c|c|c|}
\hline COUNTRY & 2007 & 2008 & 2009 & 2010 & 2011 & 2012 & 2013 & 2014 & 2015 & ACCESS \\
\hline Nigeria & 21.911 & 20.130 & 18.817 & 24.872 & 27.0 & 27,270 & 27,500 & 25,000 & N/A & $45 \%$ \\
\hline $\begin{array}{l}\text { South } \\
\text { Africa }\end{array}$ & 244.822 & 238.319 & 232.218 & 241 & 259.6 & 239,000 & 238,000 & 252 , & N/A & $75.8 \%$ \\
\hline Egypt & 118.447 & 127.968 & 131.371 & 138.729 & 138.717 & 123.900 & 136.600 & 138.700 & N/A & $99.6 \%$ \\
\hline Ghana & 6.746 & 8.133 & 8.743 & 8.213 & 11.2 & 12,024 & 12,906 & 13,071 & N/A & $60.4 \%$ \\
\hline $\begin{array}{l}\text { United } \\
\text { States }\end{array}$ & $4,156.745$ & $4,119.337$ & $3,950.332$ & $4,125.890$ & $4,100, .141$ & $4,047,765$ & $4,065,964$ & $4,093,606$ & $\begin{array}{c}4,087,38 \\
1\end{array}$ & N/A \\
\hline Brazil & 437.844 & 455. & 458 & 506 & 530.7 & 537 & 534 & 584 & N/A & $98.7 \%$ \\
\hline Russia & 962.197 & 984.641 & 939.941 & $983.8 \%$ & 996.283 & $1,071,000$ & $1,062,000$ & $1,064,000$ & N/A & N/A \\
\hline United & 370.004 & 362.122 & 351.770 & 353.455 & 342.088 & 360,612 & 356,264 & 336,043 & 337,700 & N/A \\
\hline
\end{tabular}

Kingdom

Sources: U.S. Energy Information Administration/monthly energy review may 2016,CLA World factsheet

2016, Global Energy statistical yearbook 2015,Power Africa2016,Gov. UK,Enerdata, Statistics South Africa

The table above shows that even though Nigeria's electricity generation seems to increase progressively but dropped again in 2014, it is far below other countries listed on the table except Ghana. I would be protected if I risk a conclusion that the level of electricity generation and access to it could have a cascading impact on productivity enhancement in any country under this modern era. The power sector of Nigeria is replete with tremendous crises of maintenance. Electricity facilities are not maintained leading to poor supply of power. Natural gases are maximally flared culminating in short supply which affects megawatt generation. The country is also bedevilled with inadequate transmission and distribution of the available meagre megawatts generated. EIA(2016) reports that " only $45 \%$ of Nigerians have access to electricity and actual electricity demand in Nigeria is estimated at 10,000 MW". Previous analysis on Nigeria by the International Energy Agency, World Energy Outlook (2014), Electricity Database (2012 estimate), African Development Fund (2013) pointed to this direction. The United States Energy Information Administration (2016) holds that "Nigeria has one of the lowest rates of net electricity generation per capita in the world. Those with access to electricity face load shedding, blackouts, and a reliance on private generators"(www.eia.gov). A 2010 Harvard paper, estimated that "more than $30 \%$ of electricity is produced by inefficient private generators. Businesses often purchase costly generators to use as back-up power supply during outages. Most Nigerians use off-grid traditional biomass and waste, such as wood, charcoal, and animal dung, to fulfill household energy needs, such as cooking and heating" (EIA, 2016).

In driving home this argument, let us look at the continental distribution of electricity productivity across the world.

TABLE 2: Electricity Distribution among Continents

\begin{tabular}{lccccc}
\hline CONTINENTS & $\mathbf{2 0 0 7}$ & $\mathbf{2 0 0 8}$ & $\mathbf{2 0 0 9}$ & $\mathbf{2 0 1 0}$ & $\mathbf{2 0 1 1}$ \\
\hline Africa & 580,435 & 586.320 & 594.085 & 631.523 & N/A \\
Asia & $6,568.210$ & $6,773.339$ & $7,072.953$ & $7,689.254$ & N/A \\
Europe & $3,590.043$ & $3,620.604$ & $3,454.395$ & $3,610.298$ & N/A \\
Eurasia & $1,409.638$ & $1,429.510$ & $1,358.834$ & $1,423.480$ & N/A \\
North America & $5,022.134$ & $4,991.921$ & $4,795.984$ & $4,974.219$ & N/A \\
South America & $1,004.637$ & $1,038.542$ & I,043.545 & $1,096.177$ & N/A \\
\hline
\end{tabular}

SOURCE: US Energy Information Administration

Table 2 above shows that Asia is high in electricity production followed by North America, Europe, Eurasia, South America and lastly Africa. It would therefore not be risky to conclude that Africa will not get anywhere in terms of general productivity with this low productivity in electricity?

\section{THE PLACE OF POLICY IN OVERALL PRODUCTIVITY ENHANCEMENT}

Enhancing productivity would suggest that government gets the appropriate policy setting right. One way policy can contribute to increase productivity is to consider Nigeria's productivity level in relation to world's best practices - the global technology frontier. Gruen (2012) has argued that the global stock of technology obviously determines what is possible to produce within given resources and how.

Nigeria's drive towards maximizing its productivity growth in future to compete favourably with other productive economies will depend on its capacity to move with advances in technology. Nigeria has remained a 
limited adaptor or user of advances in technology. It has not also shown sufficient effort in generating indigenous technology to drive productivity. Nigeria's worry has always been on agriculture and oil productivity without considering what infrastructure we have indigenously to ensure such productivity. So long as we do not develop indigenous technology, to address sectoral productions, productivity would continue to nose-dive. This is so because expenditure on received technologies has depleting effect on overall productivity.

\section{COMPETITIVENESS AND PRODUCTIVITY: A RELATIONAL DISCOURSE}

Competitiveness as a development term has been described variously in productivity discourse. While some attempt to equate the term with productivity others attempt a clear-cut distinction. What does this term suggest?The World Economic Forum's Global Competitiveness Report conceives of the term as the "set of institutions, policies, and factors that determine the level of productivity of a country" (Tambovceva \&Tambovceva, 2014). In a broader sense, though not quite different IMD's World Competitiveness Yearbook defines it "as how an economy manages the totality of its resources and competencies to increase the prosperity of its population" (www2.itif.org). Even though these terms seem related, competitiveness should not be confused with productivity (Atkinson, 2013). The reason is that productivity of a firm could be felt within and outside of its geographical location while competitiveness speaks of a firm's interaction in oversea markets.

A true connotation of competitiveness therefore, is the "ability of a region to export more in value added terms than it imports" (Atkinson, 2013). Economic policies of large discounts to exporters and restrictions to imports runs counter to true competitiveness. A major component of competitiveness is trade surplus which a country must possess. In other words, a country must develop a robust traded sector industry to reap the needed benefit of productivity. "A traded industry is one where the firms sell a significant share of their output outside a particular geographical area" (Atkinson, 2013), preferably outside the shores of its national territory.

A competitive economy therefore, is "one with a trade surplus, few barriers to imports and limited discounts to exporters". This is where developing economies run into problem with their infant industries. Where barriers are not placed on some imports, how would emerging industries in those sectors grow? Again where exporting firms are not assisted in terms of discounts how can they measure up in terms of export production? From a pure capitalists' perspective, these barriers and assistance must be eliminated if a country is to be involved in actual competition in world market economy. But can traded firms in developing economies do well without public institutional support? From a radical political economy perspective, elimination of trade barriers would mean the saturation of backward economies with goods and services from major industrial nations. This scenario has a high debilitating effect on the growth of home industries.

The concept of productivity and competitiveness reinforces each other. Productivity growth can propel competitiveness. Where a country has production surplus in traded areas, it could be pushed to look for markets to dispose them. The best place in this case is the oversea market. Productivity may not propel competitiveness if it is concentrated on non-traded sectors. On the other hand effective competition can encourage productivity; the result of which will be an improvement in the standard of living of the people.

It is a fact under the current global capitalist economy that countries with effective traded sector competitiveness generate enough foreign exchange for their local economy.

The table below captures this position clearly.

TABLE 3: Export of selected countries by one month

\begin{tabular}{|c|c|c|c|}
\hline COUNTRY & EXPORT VALUE & MAJOR EXPORTS & EXPORT PARTNERS \\
\hline China & $\begin{array}{l}\text { 171.2b USD in April } \\
2016\end{array}$ & $\begin{array}{l}\text { Electromechanical } 57 \% \text {, } \\
\text { labour intensive products of } \\
\text { e.g clothing, textiles, } \\
\text { furniture, toys bags, foot } \\
\text { wears } 20 \%\end{array}$ & $\begin{array}{l}\text { US } 17 \% \text {, EU } 16 \% \text {, ASEAN } \\
10 \% \text {, Japan } 7 \%\end{array}$ \\
\hline United States & $\begin{array}{l}\text { 182.7b USD April, } \\
2016\end{array}$ & $\begin{array}{ll}\text { Industrial supplies } & 28 \% \text {, } \\
\text { capital goods }(39 \%), & \text { food } \\
\text { feeds beverages } & 12 \% \text {, } \\
\text { automotive vehicles, parts } \\
\text { engine } 12.5 \% \text {. }\end{array}$ & $\begin{array}{l}\text { Canada 19\%, EU 17\%, } \\
\text { Mexico 14\%, China } 7 \% \text {, } \\
\text { Japan 5\% }\end{array}$ \\
\hline Nigeria & $\begin{array}{l}1,128 b \text { USD march } \\
2016\end{array}$ & $\begin{array}{l}\text { Oil and natural gas } 95 \% \text { of } \\
\text { total export }\end{array}$ & $\begin{array}{l}\text { US } 13 \% \text {, Africa } 12 \% \text {, Asia } \\
29 \% \text { Europe } 43 \% \text { Brazil } 3 \% \text {, }\end{array}$ \\
\hline
\end{tabular}


Ghana

2.2b USD september 2015
Gold, Cocoa beans, timber products, Tona, aluminum, diamond, manganese ore, horticulture

SOURCES: Trading Economics, 2016, Ministry of Commerce, China, US Census Bureau 2016, Nigeria's National Bureau of statistics 2016.

The table above shows that in April 2016, China exported goods worth over 171.2 billion dollars, the United States in April 2016 exported goods worth 182.7 billion dollars, and Ghana exported goods worth 2.2 billion dollars in September 2015 while Nigeria exported goods worth 1.128 billion dollars in March 2016. A look at the export items of these selected countries would reveal that while the rest are involved in export product diversification, Nigeria's major mono export is oil and natural gas and occupies $91 \%$ of its total export. It is evident clearly that Nigeria is not involved in any form of effective competition because it is not involved in much of creative productivity (Effective manufacturing). Mojeed (2016) had reported that Nigeria's export dropped by 52 percent in April 2016. This drop in export value could be attributed to the fact that the demand for Nigeria's major export commodity (oil) is declining geometrically in the international market,

Do we blame this on the international division of labour as argued by radical political economists such as Claude Ake, Samir Amin, AndreGunder Frank, Eskor Toyo, Bade Onimode, Aja AkpuruAja etc.? The approach argues that Nigeria as a colony was designed to produce raw materials and serves as markets for finished western goods.

The International economic order already sees you as a producer of primary goods (Ijim Agbor, 2013). What certainly does Nigeria produce in terms of industrial goods for export to attract foreign exchange sufficient enough to address Nigeria's economic problem? Does a country compete effectively with perishable raw materials or substandard produced non-tradable goods? Does Nigeria posses the confidence to compete? Otherwise why does it produce the little it can and label it made in other known countries? If Nigeria must compete effectively its productivity should shift to the area of industrial manufacturing (productivity change) because a non-manufacturing economy is an economy in retrogression.

\section{ENCUMBRANCES TO CREATIVE PRODUCTIVITY IN NIGERIA}

Nigeria's productivity woes can be blamed on several factors. One very damaging factor is the rentier mentality of the system. The rentier theory argues that countries that depend so much on oil revenue predominantly generated from external markets tend to become too unaccountable to their citizens and autocratic. Cheap access to oil revenue by rentier state leaders creates the mentality of corruption and retrogression in overall development of the society. This theory explains why some countries with abundant oil wealth perform worst than their resource-poor counterparts. The basic characteristic of a rentier state is that there is a clear absence of adequate effort to generate revenue from domestic manufacture arising largely from the presence of their naturally endowed wealth. The enormous oil wealth puts their minds away from investing in critical infrastructure that propels productivity. The theory of rentier state has been used to explain the prevalence of authoritarian regime types in the Middle East as well as Africa and a conspicuous absence of responsible democratic practices in these regions.

Another problem is lack of leadership commitment (Political will). This of course covers corruption, as well as leadership ineptitude. The governing and entrepreneurial elites we have are largely those of bazaar mentality. Part of why resource diversification is difficult in Nigeria has been the compradoral (Middle Men) and bazaar mentality (quick profit i.e. immediate profit) of leaders and entrepreneurs (Ijim Agbor, 2012). Attitude to governance is therefore highly transactional (what one can get out of it) as against transformational ideas and commitment. For such leaders therefore, investing in critical infrastructure development is a waste of time since it is likely to take much time to achieve return on investment. They may not be in power to criminally exploit the benefit of such investment especially within the backdrop of tenure limit of elective offices specified by law.

\section{ENSURING CREATIVE PRODUCTIVITY FOR NATIONAL} TRANSFORMATION IN NIGERIA

In terms of competing in the global economic arena, Nigeria is not very strong. Part of this is because the direction of productivity needed for such competition is absent. Nigeria mono economic practice is a major threat to evolving creative productivity. It is a trend that the country needs to overcome if it must come out of this crossroad.The starting point as candidly opined here is to start a massive exercise in resource diversification. I suggest two forms of diversification: Lateral (horizontal) and structural (vertical) diversification of resources (Ijim Agbor, 2012).Lateral diversification involves the use of oil money to invest in Agriculture, Agro Allied industries and solid minerals in order to make them become viable economic sectors 
for effective revenue generation. Structural diversification is the investment of oil money in critical infrastructure such as iron and steel, science and technology, energy, machinery, fabrication and design industries. This is a diversification that addresses manufacturing; a key element in competitiveness (Ijim Agbor, 2012).

There is need also for a robust collaboration between the state, academia and industry. The Helix model indicates a relatively equal and interdependent relationship between the institutional spheres of university, industry and government which overlap and compliment the role of the other. This model promotes a relationship between the state, academic and industry as an emerging collaboration in economic development. As argued by Etzkowitz, Gulbrandsen and Levitt, (2000) strong boundaries by development institutions are no longer fashionable but a conscious overlapping system of compliments among the state, academia and industry. Wessner (1999) submits also that Government has to encourage collaborative Research and Development among firms, universities and national laboratories to address issues of national competitiveness. The tripartite relationship sees the state getting involved or interested in what happens in other institutional spheres. The academia is alive to its research responsibility with committed support from the state. The urge to become more creative and innovative becomes high because the resources to carry out ground-breaking researches are readily provided by the state and in some cases by the industries. The industries on the other hand are committed to applying research outcomes.

A relationship of this kind of cooperation produces a knowledge-base economy where the state has within its kitty a possible idea of its overall economic development. Where innovative researches are initiated and funded and the outcome applied, it speeds up the overall development of society and creates opportunities for people to address their personal economic needs. A substantial exercise in this direction removes so many people from dependence and prepares them towards self-reliance.

\section{CONCLUSION}

The notion of productivity and competitiveness are very vital in the transformation drive of any capitalist socio-formation. Advance capitalist societies such as China and the United States have been able to grow their economy substantially because of their high productivity rate and their involvement in overseas markets.Nigeria cannot fit in appropriately because it lacks the elements of competition needed in international market. High productivity is important because it possesses the capacity to improve an economy in general and the standard of living of citizens in particular. Many factors that determine productivity such as technological knowledge, physical and human capital are poorly developed in Nigeria. The state needs to take productivity seriously because in its traded form, it could spur competitiveness which also possesses the tendency to rake in foreign exchange for further investment. Unfortunately, the desire for traded productivity is grossly encumbered by Nigeria's rentier mentality, general character of complacency and poor attitude to governance. Nigeria will overcome this lag by finding a rescue in resource diversification and effective collaboration between the state, academia and the industry in the development of knowledge base economy. Nigeria requires firm political will exemplified in strong and focused institutions to overcome its economic quagmire. It requires robust effort at increasing production input such as technological knowhow, improved manpower, capital and an effective exercise in productivity change. Major countries with hitherto similar economic challenges took a serious exercise in productivity enhancement.

\section{REFERENCES}

[1] Abowd, J. M. etal(2005). The relationship among Human Capital, Productivity and

[2] market value: Building up from Micro Evidence Economy. In Corrado, C.,

[3] Haltiwanger, J. and Daniel Sichel (Eds).Measuring capital in the new Economy.

[4] Chicago and London: University of Chicago Press. pp 153-98.

[5] African Development Fund, (December 2013) "Project Appraisal Report: Partial Risk Guarantee in Support of the Power Sector Privatizations," pages 1-8.

[6] Atkinson, R. D. (2013). Competitiveness, Innovation and Productivity: Clearing up

[7] the confusion. www.itif.

[8] Energy Information Administration (2016). Analysis on Nigeria. www.eia.gov/beta/international/analysis

[9] Gruen, D. (2012). Importance of productivity.Caribera, the Treasury, Australian

[10] Government.

[11] Harvard, Program on the Global Demography of Aging, (October 2010). "Nigeria: The Next Generation Report," PGDA Working Paper No. 62, page 47

[12] Hubbard, T. N. (2003). Information, decisions, and productivity: On-board

[13] computers and capacity utilization in Trucking. American Economic Review 93(4):

[14] 1328-53.

[15] Ijim Agbor (2012). Political Economy of Nigeria. A Paper presented on Resource 
[16] Diversification for sustainable economic development in Nigeria to the participants of the Senior Executive Sec. No. 24 (2013) of National Institute Kuru, Jos.

[17] Ilmakunmas, P. Maliranta, M. and Vainiomaki, J. (2004). The roles of employer and

[18] Employee characteristics for plant productivity. Journal of Productivity Analysis,

[19] 21 (3) 249-76.

[20] Mojeed, O. (2016). Nigeria Export drops by 52\% in 2016 - NBS. PZI People, www.pzimedia.com

[21] OECD Productivity Manual (2001). A guide to the measurement of industry - level

[22] and aggregate productivity growth, Paris.

[23] Samiee, S. (1990).Productivity, Planning and Strategy in Retailing. California

[24] Management Review, 32 (2) 56-69.

[25] Schreyer P. (2001). Measuring productivity: Measurement of Aggregate is industry level productivity growth: OECN Manual: Paris and Washington D.C.

[26] Organization for Economic cooperation \& Development.

[27] Syverson, C. (2011). What determines productivity? Journal ofEconomic Literature,

[28] 49 (2) 326-365.

[29] Tambovceva, T. and Tambovceva, A. (2014). Competitiveness of Nano Technology. Advanced Material Search. www.scientific.net

[30] Ubeku, A. (1983). Productivity, wages, prices and continued employment. In A.

[31] Osoba (Ed.) Nigerian Institute of Social and Economic Research National

[32] Conference on Productivity in Nigeria. Ibadan: NIGER pp 377-388.

[33] Udo-Aka, U. (1989).Measuring Productivity. Pp 56-69.

[34] Watson, T. (1963).A Business and its Beliefs. New York: McGraw-Hill.

[35] World Competitiveness yearbook (2012) (imd) World Competitiveness Centre.

[36] www.imd.org 